\title{
Strength and Ductility of RC Columns Retrofitted by FRP under Cyclic Loading
}

\author{
Tavio $^{1}$, Karmila Achmad ${ }^{2}$, Parmo $^{3}$, and Agus Sulistiawan ${ }^{4}$
}

\begin{abstract}
Rapid increasing of population and limited city area as well as better awareness on the green open area of the city, which is ideally about 30 percent, have forced the development of the buildings vertically. The increasing number of high-rise buildings and skyscrapers are the evidence that the development of the buildings in the cities of Indonesia are heading towards the over-ground space. However, the vertical development is known to be highly vulnerable to earthquake hazard. The revised Indonesian seismic map has increased the seismic load in most of the seismic zones in Indonesia. To create a safe and healthy city, a comprehensive urban planning and design is required. A good urban planning and code-based design must also be adopted to assure a safe building structure for the dwellers. This study is intended to observe the possibility of using alternative materials to improve the performance of the existing buildings which have not followed the existing earthquake-resistant building code through the implementation of Fiber Reinforced Polymer (FRP) wrap on structural members. The strength and ductility enhancements of the columns retrofitted with external confinement using FRP are found when compared with the unconfined control column. The results indicated that the maximum loads of each confined columns have increased by 33.52, 54.97, 36.61, and 40.73 percent, respectively, for columns $C-1 G, C-1 C, C-1 R C$, and $C-1 R G$. The ductility of columns $C-1 C$ and $C-1 G$ have increased by 122.73 and 53.30 percent, but decreased by 15.24 and 66.31 for columns C-1RG and C-1RC when compared with the unconfined control column $C-1$, respectively. This is due to the unintended premature failure at the upper end of the column C-1G and an indication that the secondary fiber direction which was placed vertically has contributed to the longitudinal steel of C-1RC in increasing its capacity.
\end{abstract}

Keywords_ Cyclic Loading, External Confinement, FRP, Over-Ground Space, Retrofit, Structural Strengthening.

\section{INTRODUCTION}

$\mathrm{C}$ urrently rapid development of the cities in Indonesia tends towards the over-ground space. It is indicated by the development of high-rise buildings and skyscrapers in many cities of Indonesia. This is due to the rapid growth of the citizens and the limited city area. Furthermore, there is a Green Spatial Arrangement Policy, which requires at least 30 percent of the city area for green open space. However, a poor planning and design of a building structure on the over-ground space has led it vulnerable to the seismic hazard. This is even exacerbated by the location of Indonesia in the ring of fire belt. Indonesia lies on the unstable faults and nearby the subduction zones of tectonic plates, i.e. Eurasia, Pacific, and Indo-Australia. The latest seismic map of Indonesia has accommodated the increase of earthquake vulnerability of the buildings in Indonesia by increasing the design earthquake load.

There are two important things to be considered when designing a structure, namely the strength and ductility. The strength of a structure deals with the indication of strength increase beyond the initial capacity. The ductility of a structure deals with the sign of better postpeak response beyond the peak to prevent a brittle failure due to the earthquake which can bring to the sudden collapse of a building. The increase of seismic intensities in several seismic zones in Indonesia (SNI 1726-2012 [1]) has challenged the designer and expert to come up with an innovative solution to meet the latest building code requirements [2] for the existing buildings which

\footnotetext{
${ }^{1}$ Tavio is with Departement of Civil Engineering, Faculty of Civil Engineering and Planning, Institut Teknologi Sepuluh Nopember, Surabaya, 60111, Indonesia. E-mail: tavio@ce.its.ac.id.

${ }^{2}$ Karmila Achmad is with Departement of Civil Engineering, Politeknik Negeri Balikpapan, Kalimantan, Indonesia.

${ }^{3}$ Parmo is with Departement of Civil Engineering, Universitas Negeri Malang, Malang, Indonesia.

${ }^{4}$ Agus Sulistiawan is with Ministry of Public Works, Manokwari, Indonesia.
}

have been constructed and designed in accordance with the earlier seismic map and building code versions [3].

Column plays a very important role in a building since the failure of columns might lead to a fatal collapse of a building. Moreover, the columns in a building are very vulnerable to seismic strike. Therefore, an intensive research studying the possibility of improving the columns to withstand the seismic load is deemed necessary. In the research, the seismic load is simulated by cyclic loading [4-13].

Previous researches carried out by other mainly focused on circular reinforced concrete columns confined by Fiber Reinforced Polymer (FRP) wrap. Very little study has been conducted on square or rectangular reinforced concrete columns confined with FRP wrap [14]. The square columns are more popular and commonly used in a building rather than circular columns. Additionally, the behaviors of square and circular columns are totally different since square columns have much lower confining effectiveness rather than the circular ones [15-25]. Thus, in order to better understand the seismic behavior of the square reinforced concrete columns confined by FRP wraps, several column specimens were designed, cast, experimentally tested in the laboratory under cyclic loading, and examined.

\section{METHOD}

\section{A. Specimen Details}

Five column specimens observed in the study are as follows: (1) one unconfined reinforced concrete column as a control specimen; (2) two reinforced concrete columns wrapped with a single layer of CFRP and GFRP as external confinement prior to cyclic loaded; and (3) two unconfined reinforced concrete columns which underwent the first stage of cyclic loading to simulate the medium earthquake until they have reached lateral drift ratio of 2.2 percent prior to be repaired by the injection 
grouting. These columns continued to undergo the second stage cyclic loading after retrofitted with CFRP and GFRP wraps as external confinement.

All five column specimens prepared and cast in the research were identical. The last two specimens described above underwent two-stage cyclic loadings, so that totally there were seven times of cyclic loadings conducted. The designations of the specimens are as follows: (1) the unconfined column specimen (C-1), (2) the column specimens confined by GFRP (C1-G) and CFRP (C-1C), and (3) the column specimens retrofitted with GFRP (C-1RG) and CFRP (C-1RC). The dimensions of the reinforced concrete column specimens were all the same, i.e. $350 \times 350 \mathrm{~mm}$ with an effective height of $1100 \mathrm{~mm}$. The longitudinal bars used in the columns are eight $19 \mathrm{~mm}$-diameter deformed bars. The diameter of transverse steel used is $10 \mathrm{~mm}$ spaced at 200 $\mathrm{mm}$.

\section{B. Test Setup}

The experimental test was carried out at the Center for Research and Development of Settlement, Ministry of Public Works, Bandung, Indonesia. The column specimens were positioned standing vertically in a loading frame which was mounted on the strong laboratory floor. The complete test setup with a column specimen ready for test can be seen in Figure 1. The axial load was retained constantly during the test, while the cyclic loading was variously applied to the column specimens.

\section{Injection and FRP-Wrap Application}

Injection agent used for sealing the cracking of concrete after first-stage loading of column specimens C1-RG and C1-RC was a combination of MC-Fastpact 1264 and epoxy resin MC-Dur 1200. In order to obtain an optimum result, the injection process must be conducted several times at every injected point. Once the injection was done completely, the columns were allowed to cure for approximately 24 hours thereafter, and they were ready for implementation of FRP-wrap (column specimens C-1RG and C-1RC).

The FRP-wrap application used a wet lay-up method with full jacketing installment. The main fiber direction is oriented horizontally with $200-\mathrm{mm}$ overlap. A single layer of FRP was applied for the overall height of the column specimens. Additional two layers were wrapped at the upper part of the column specimens (775 mm long from the top of the columns). These additional layers were introduced to avoid any failure at the non-test regions. The FRP-wrap application on the column specimens $\mathrm{C}-1 \mathrm{G}$ and $\mathrm{C}-1 \mathrm{C}$ were carried out only after the concrete surfaces dried prior to the cyclic loadings. For retrofitted column specimens, the FRP-wrap applications were introduced after injected with the grouting agent to repair the cracks and damages due to the first stage of cyclic loading.

The investigation is basically an experimental study on the effects of the change of a discharge valve seat (from a profile that is provided by the OEM) on the vibration and cylinder chamber pressure characteristics of a singlestage, single-acting air reciprocating compressor. The study is conducted in several working pressures.

The aim of the study is to know the effects in vibration and cylinder chamber pressures when there is a change of the geometry of a discharge valve seat. The results are intended to become a reference for those who are interested designing a valve seat profile, in order to increase durability and performance of a reciprocating compressor. The air reciprocating compressor with an unmodified discharge valve seat becomes a baseline to which results of modified valve seats to be compared. The discharge port is chosen because the high pressure happens in a discharge stage (compared to a suction step).

\section{RESULT AND DISCUSSION}

\section{A. Mode of Failure}

Initial crack occurred on the unconfined column specimens was a curved crack located in the plastic hinge region. The maximum load $P_{\max }$ of $278.9 \mathrm{kN}$ was attained at lateral drift ratio of 2.75 percent in the first cycle. The mode of failure of column specimen C-1 is illustrated in Figure 2. The mode of failure of column specimen $\mathrm{C}-1 \mathrm{G}$ was characterized by the crushing of concrete and the torn-off of FRP wrap. At lateral drift ratio of 3.5 percent during the first cycle of cyclic loading, the column head was failed indicated by the concrete crush and the GFRP wrap was torn off at the column corners. The highest load achieved during the test of column specimen C-1G was $372.4 \mathrm{kN}$. The test was continued with no axial load applied which caused the lateral load-displacement curve dropped drastically. When the lateral load reached $142.6 \mathrm{kN}$ with the displacement of $56.78 \mathrm{~mm}$, the failure of GFRP wrap in the plastic hinge region began to be visible. The mode of failure of column specimen C-1G is depicted in Figure 3. The failure of column specimen $\mathrm{C}-1 \mathrm{C}$ was indicated by the change of the FRP resin color and the damaged surface of the concrete in the plastic hinge region. The maximum load $P_{\max }$ was $432.2 \mathrm{kN}$ at lateral drift ratio of 5 percent during the first cycle of loading. The final condition of column specimen C-1C is shown in Figure 4. The failure of column specimen C-1RG was initiated by the concrete spalling and GFRP torn-off. The maximum load $P_{\max }$ achieved was $414.6 \mathrm{kN}$ at lateral drift ratio of 5.0 percent. The concrete spalling was occurred at lateral drift ratio of 5.5 percent at lateral load of $326.3 \mathrm{kN}$. The failure of column specimen C-1RG occurred in the second stage of cyclic loading is shown in Figure 5. In the second stage of cyclic loading, the failure of column specimen C-1RC was due to the crushing of the concrete and the torn-off of CFRP in the plastic hinge region. The maximum lateral load was noted at $392.5 \mathrm{kN}$ with a maximum displacement measured from LVDT2 of $65.48 \mathrm{~mm}$. The failure of column specimen C-1RC during the second stage of cyclic loading is shown in Figure 6.

\section{B. Lateral Load-Displacement Relationship}

Based on the $P$ - $\delta$ curve, the phenomenon occurred during the test could be determined for column specimens C-1, C-1G, C-1C, C-1RG, and C-1RC. The maximum load $P_{\max }$ were $278.9 \mathrm{kN}, 372.4 \mathrm{kN}, 432.2 \mathrm{kN}$, $381.0 \mathrm{kN}$, and $392.5 \mathrm{kN}$. The maximum lateral displacements $\delta_{\max }$ were measured as follows: $53.24 \mathrm{~mm}$, $56.78 \mathrm{~mm}, 96.46 \mathrm{~mm}, 56.56 \mathrm{~mm}$, and $65.48 \mathrm{~mm}$, respectively, for column specimens C-1, C-1G, C-1C, C$1 \mathrm{RG}$, and C-1RC. The maximum percentages of 
increased load to column specimen C-1 were 33.52 percent, 54.97 percent, 36.61 percent, and 40.73 percent for $\mathrm{C}-1 \mathrm{G}, \mathrm{C}-1 \mathrm{C}, \mathrm{C}-1 \mathrm{RG}$, and $\mathrm{C}-1 \mathrm{RC}$, respectively. The maximum percentages of increased lateral displacement $\delta_{\max }$ to column specimen C-1 were 6.65 percent, 81.18 percent, 6.24 percent, and 22.99 percent for column specimens C-1G, C-1C, C-1RG, and C-1RC, respectively. The maximum percentages of increased stiffness to column specimen C-1 were 32.41 percent, 55.36 percent, 33.77 percent, and 42.89 percent, respectively, for column specimens C-1G, C-1C, C-1RG, and C-1RC. The complete lateral load-displacement curves can be seen in Figure 7.

Based on the analysis of the $P-\delta$ curves, the displacement ductility $\left(\mu_{\delta}\right)$ of each column specimen can be determined. The displacement ductility $\mu_{\delta}$ for column specimen C-1, C-1G, C-1C, C-1RG, and C-1RC were $5.44,4.75,11.89,10.38$, and 2.17 , respectively. The increase of the displacement ductility of column specimens C-1C and C-1RG were 118.68 and 90.81 percent, respectively. However, there were unexpected failure occurred on column specimens C-1G and C-1RC during the test, the displacement ductilities of both columns have decreased. The cause of the decrease of displacement ductility of column specimens C-1G compared to column C-1 was the failure of the column head during testing which has caused the test was continued with no any axial load applied. This caused the displacement ductility decreased by 12.74 percent. For column specimen C-1RC, the displacement value has also decreased by 60.11 percent compared to column specimen C-1 (control column) since the longitudinal steel bars have yielded during the late stage of testing. This has caused the ratio of the ultimate to yield displacement became low. In addition, there was an indication that the secondary carbon fiber in vertical direction has strengthened the longitudinal steel bars of the column, which in turn, has increased the capacity of the column specimen $\mathrm{C}-1 \mathrm{RC}$ which was higher than that of column specimen C-1.

\section{Moment-Curvature Relationship}

Based on the analysis moment-curvature relationship, there was an increase in the maximum moment capacity for confined and retrofitted column specimens compared to the unconfined column specimen, either for GFRP and CFRP wraps, as illustrated in Figure 8. The maximum moments of all column specimens were $328.04 \mathrm{kN}-\mathrm{m}$, $434.37 \mathrm{kN}-\mathrm{m}, 509.63 \mathrm{kN}-\mathrm{m}, 438.83 \mathrm{kN}-\mathrm{m}$, and 468.73 $\mathrm{kN}-\mathrm{m}$ for column specimens C-1, C-1G, C-1C, C-1RG, and $\mathrm{C}-1 \mathrm{RC}$, respectively. Based on the analysis of the moment-curvature relationships, it can be shown that there were increases in maximum moment $M_{\max }$ when compared to column specimen C-1, namely 32.41 percent, 55.36 percent, 33.77 percent, 42.89 percent for column specimens C-1G, C-1C, C-1RG, and C-1RC, respectively.

The curvature ductility for column specimens $\mathrm{C}-1$, C$1 \mathrm{G}, \mathrm{C}-1 \mathrm{C}, \mathrm{C}-1 \mathrm{RG}$, and C-1RC were 5.61, 4.76, 12.51, 8.60, and 1.89, respectively. Similar to the displacement ductility, the increased curvature ductility for column specimens $\mathrm{C}-1 \mathrm{C}$ and $\mathrm{C}-1 \mathrm{RG}$ compared to column specimen C-1 were 122.73 percent and 53.30 percent. The curvature ductility of column specimens C-1G and
C-1RC were decreased by 15.24 percent and 66.31 percent compared with column specimen C-1.

\section{CONCLUSION}

Based on the results of the research of strengthened and retrofitted square reinforced concrete column specimens using GFRP and CFRP external confinement methods subjected to cyclic loading, it can be concluded as follows:

A. From the three parameters measured during the test, i.e. $\mathrm{P}_{\max }, \delta_{\max }$, and $\mathrm{M}_{\max }$, there was an increase of strength of all strengthened and retrofitted column specimens with FRP wrap compared to the unconfined column specimen.

1) From the maximum load $P_{\max }$, the increases to column specimen C-1 were 33.52 percent, 54.97 percent, 36.61 percent, and 40.73 percent for column specimens C-1G, C-1C, C-1RG, and C$1 \mathrm{RC}$, respectively.

2) From the maximum lateral displacement $\delta_{\max }$, the percentages of increase of column specimens $\mathrm{C}$ 1G, C-1C, C-1RG, and C-1RC to column specimen $\mathrm{C}-1$ were 6.65 percent, 81.18 percent, 6.24 percent, and 22.99 percent, respectively.

3) From the maximum moment $M_{\max }$, the increase of column specimens C-1G, C-1C, C-1RG, and C1RC to column specimen $\mathrm{C}-1$ were 32.41 percent, 55.36 percent, 33.77 percent, and 42.89 percent, respectively.

B. Two parameters were used to determine the increase of ductility, i.e. displacement ductility $\left(\mu_{\delta}\right)$ and curvature ductility $\left(\mu_{\varphi}\right)$. The values of $\mu_{\delta}$ and $\mu_{\varphi}$ have increased for column specimens $C-1 C$ and $C-1 R G$ and decreased for column specimens $C-1 G$ and $C$ $1 R C$.

1) The increase of displacement ductility compared to column specimen C-1 were 118.68 percent and 90.81 percent, respectively, for column specimens C-1C and C-1RG. The decrease of $\mu_{\delta}$ for column specimens $\mathrm{C}-1 \mathrm{G}$ and $\mathrm{C}-1 \mathrm{RC}$ were 12.74 percent and 60.11 percent, respectively, compared to column specimen C-1.

2) The percentage of curvature ductility increase of column specimens C-1C and C-1RG to column specimen C-1 were 122.73 percent and 53.30 percent, respectively. The decrease of $\mu_{\varphi}$ compared to column specimen C-1 were 15.24 percent and 66.31 percent, respectively.

3) The occurrence of the unexpected failure at the column head has caused the cyclic loading in the next stage must be conducted without axial load, thus, the value of displacement ductility and curvature ductility of column specimen C-1G decreased.

For column specimen C-1RC, the first yield occurred in the late stage of testing. This has caused the unexpected ratio of ultimate to yield displacement became lower. In addition, there was an indication that the secondary carbon fiber in vertical direction has strengthened the longitudinal steel bars and increased the capacity of column specimen C-1RC higher than column specimen C-1. It resulted in lower value of both 
displacement and curvature ductilities of column specimen C-1RC.

\section{ACKNOWLEDGEMENT}

The authors sincerely thank to:

a. Directorate of Research and Public Services, Directorate of Higher Education, Ministry of Education and Culture for providing the research funding.

b. Fyfe Co. LLC Singapore, PT. Fyfe Fibrwrap Indonesia, and PT. Master Solusi Indonesia, for providing the GFRP and CFRP wraps as well as its application.

c. PT. Prasetya Adi Citra Anugerah, for providing the injection grouting material and its applications.

\section{REFERENCES}

[1]. SNI 1726-2012, "Tata Cara Perencanaan Ketahanan Gempa untuk Bangunan Gedung," Badan Standardisasi Nasional, Jakarta, 2012.

[2]. RSNI 2847-201X, "Persyaratan Beton Struktural untuk Bangunan Gedung," Draft, Badan Standardisasi Nasional, Jakarta, 264 pp.

[3]. Panitia Teknik Standardisasi Bidang Konstruksi dan Bangunan. "Tata Cara Perhitungan Struktur Beton Untuk Bangunan Gedung (SNI 03-2847-2002)”. Badan Standardisasi Nasional. Bandung, 2002.

[4]. Pudjisuryadi, P.; and Tavio, "Compressive Strength Prediction of Square Concrete Columns Retrofitted with External Steel Collars," Civil Engineering Dimension, Petra Christian University, V. 15, No. 1, Mar. 2013, pp. 18-24.

[5]. Pudjisuryadi, P.; Tavio; and Suprobo, P., "Analytical Confining Model of Square Reinforced Concrete Columns using External Steel Collars," International Journal of ICT-aided Architecture and Civil Engineering, SERSC (accepted for publication in Dec. 2013 issue).

[6]. Tavio, "Interactive Mechanical Model for Shear Strength of Deep Beams," Discussion, Journal of Structural Engineering, ASCE, V. 132, No. 5, Reston, Virginia, USA, May 2006, pp. 826-829.

[7]. Tavio; Budiantara, I N.; and Kusuma, B., "Spline Nonparametric Regression Analysis of Stress-Strain Curve of Confined Concrete," Civil Engineering Dimension, Petra Christian University, V. 10, No. 1, Mar. 2008, pp. 14-27.

[8]. Tavio; and Kusuma, B., "Stress-Strain Model for High-Strength Concrete Confined by Welded Wire Fabric," Journal of Materials in Civil Engineering, ASCE, V. 21, No. 1, Jan. 2009, pp. 40-45.

[9]. Tavio; Kusuma, B.; and Suprobo, P., "Experimental Behavior of Concrete Columns Confined by Welded Wire Fabric as
Transverse Reinforcement under Axial Compression," ACI Structural Journal, V. 109, No. 3, May-June 2012, pp. 339-348.

[10]. Tavio; and Tata, A., "Predicting Nonlinear Behavior and StressStrain Relationship of Rectangular Confined Concrete Columns with ANSYS, Civil Engineering Dimension, V. 11, No. 1, Mar. 2009, pp. 23-31.

[11]. Tavio; and Teng, S., "Effective Torsional Rigidity of Reinforced Concrete Members," ACI Structural Journal, V. 101, No. 2, Farmington Hills, Michigan, USA, Mar.-Apr. 2004, pp. 252-260.

[12]. Tavio; et al., "Effects of Confinement on Interaction Diagrams of Square Reinforced Concrete Columns," Civil Engineering Dimension, V. 11, No. 2, Sep. 2009, pp. 78-88.

[13]. Teng, S.; and Tavio, "Deflections of Flat Plate Floors with Irregular Column Layout," Deflection Control for the Future, ACI SP-210, American Concrete Institute, Farmington Hills, Michigan, USA, 2003, pp. 37-63.

[14]. Cole, C. and Belarbi, A. "Confinement Characteristics of Rectangular FRP-Jacketed RC Columns", Proceedings of the Fifth International Symposium on Fiber Reinforced Polymer for Reinforced Concrete Structures (FRPRCS-5), Cambridge, UK, July 16-18, 2001, pp. 823-832.

[15]. Benzaid, R, Chikh NE and Mesbah H. "Behaviour Of Square Concrete Column Confined With GFRP Composite Warp”, Journal Of Civil Engineering And Management, 2008.

[16]. ACI 440.2R-02. "Guide for the Design and Construction of Externally Bonded FRP Systems for Strengthening Concrete Structures”. ACI Committee 440, 2002.

[17]. ACI 440.3R-04. "Guide Test Methods for Fiber-Reinforced Polymers (FRPs) for Reinforcing or Strengthening Concrete Structures”. ACI Committee 440, 2004.

[18]. ACI 374.1-05. “Acceptance Criteria for Moment Frames Based on Structural Testing and Commentary”. ACI Committee 374, 2005

[19]. Bank, Lawrence. "Structural Design with FRP Materials" John Wiley \& Sons, INC, Canada, 2006.

[20]. Gangarao, H, Taly, N and Gangarao, H. "Reinforced Concrete Design with FRP Composites" CRC Press, Prancis, 2007

[21]. Park, R and Paulay,T.”Reinforced Concrete Structures” John Wiley and Sons, Canada, 1975.

[22]. Lee, Chung-Sheng, Hegemier, GA and Philippi DJ. “Analitical Model for Fiber Reinforced Polymer Jacketed Square Concrete Columns in Axial Compression” ACI Structural Journal, 2010 pp.208-217.

[23]. Tavio, Purwono, R dan Rosyidah, A. "Peningkatan Daya Dukung dan Daktilitas Balok Beton Bertulang Dengan Menggunakan Perkuatan CFRP (Carbon Fiber Reinforced Polymer” Dinamika Teknik Sipil, 2009.

[24]. Watanabe, K, Niwa, J, Yokota, H and Iwanami, M. "Stress-Strain Relationship for the Localized Compressive Failure Zone of Concrete under Cyclic Loading”.

[25]. Sheikh, SA and Liu, J. "Enhancing Seismic resistance of Concrete Columns with FRP” Proceedings fib Symposium PRAGUE, 8-10 June 2010.

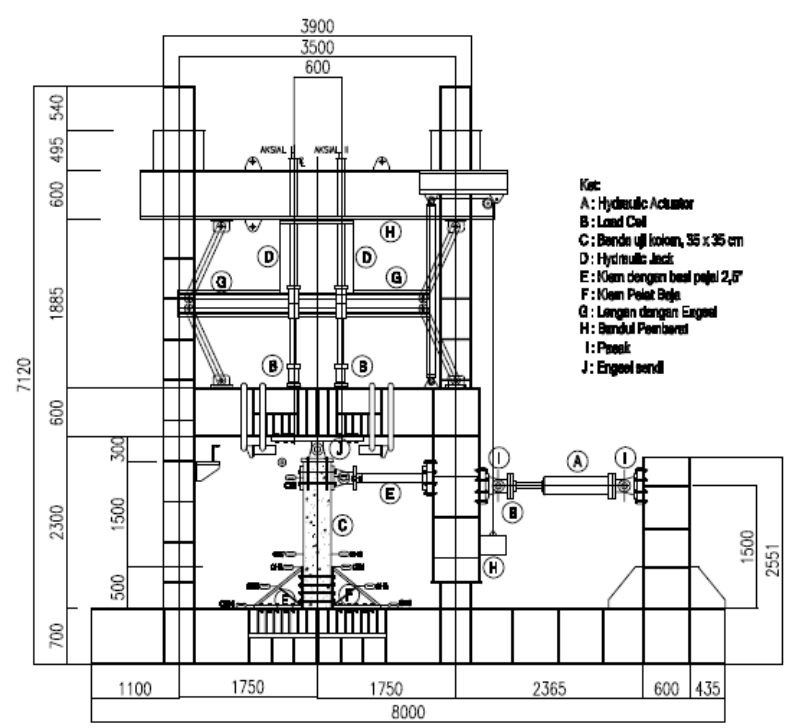

Figure 1. Column specimen test setup 


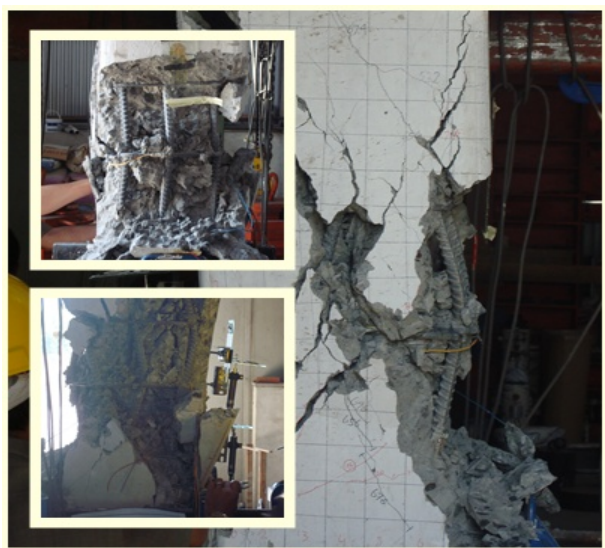

Figure 2. Failure of column specimen C-1

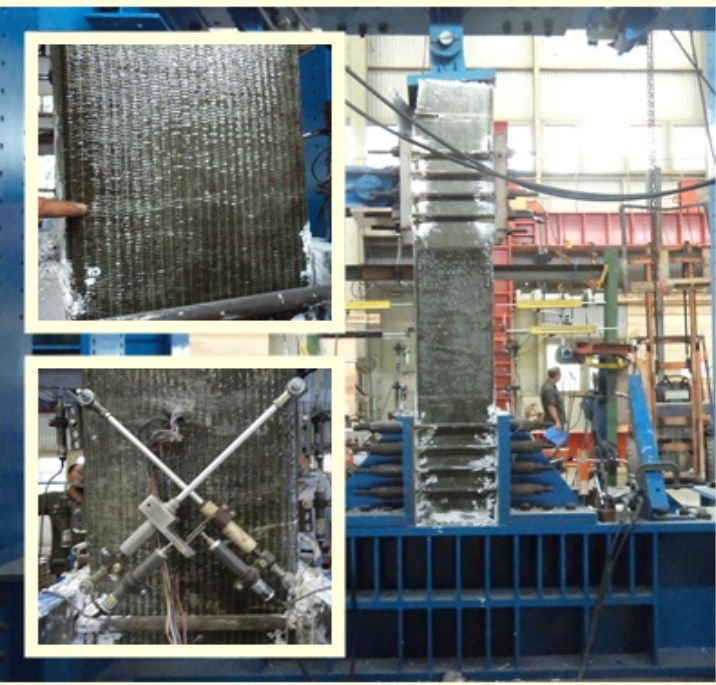

Figure 3. Failure of column specimen C-1G
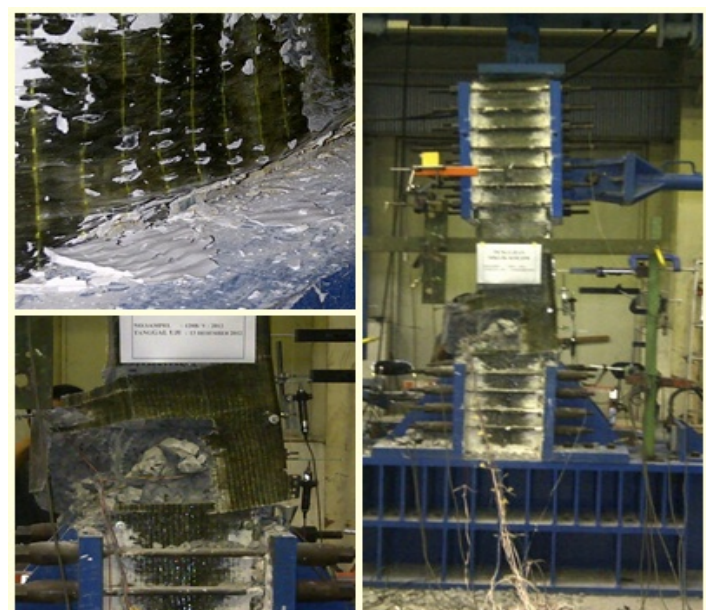

Figure 5. Failure of column specimen C-1RG
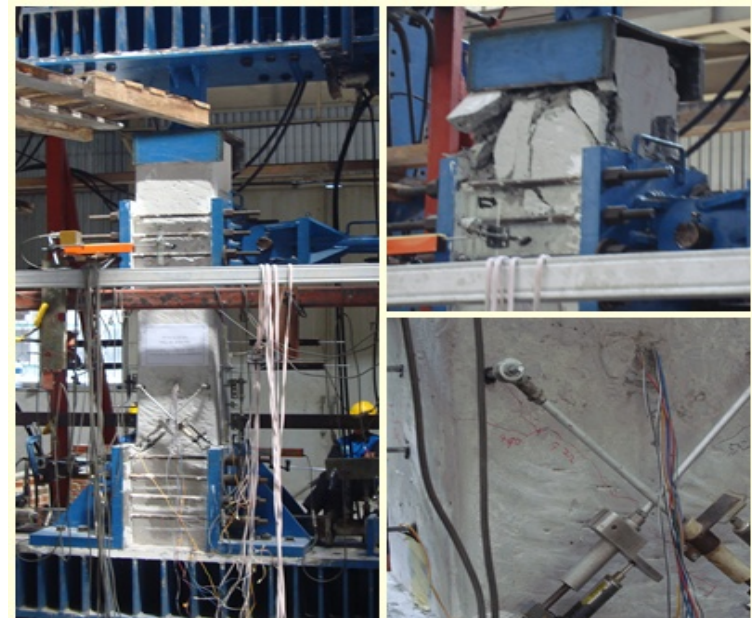

Figure 6. Failure of column specimen C-1RC

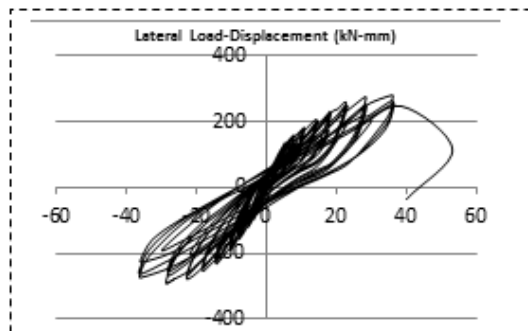

(a)

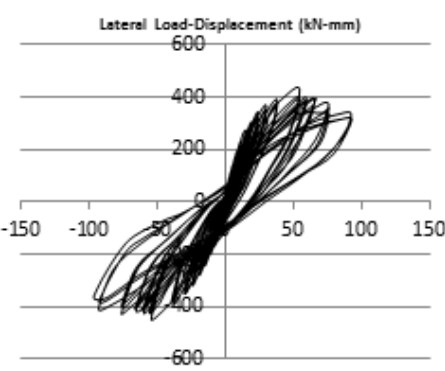

(b)

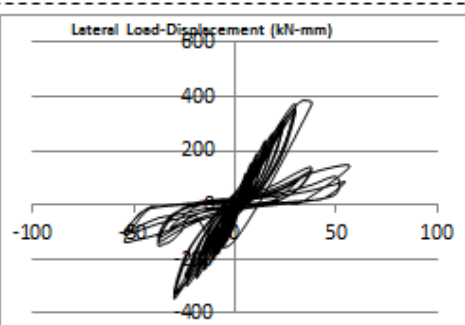

(b)

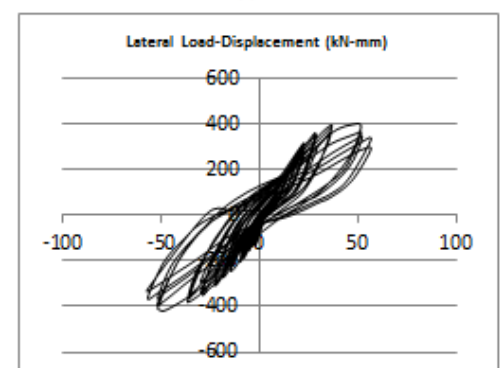

(d)

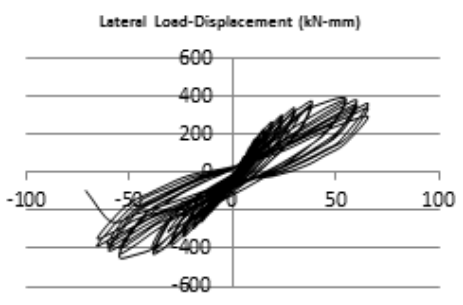

(e)

Figure 7. Lateral Load-Displacement Curves: (a) C-1; (b) C-1G; (c) C-1C; (d) C-1RG, and (e) C-1RC 


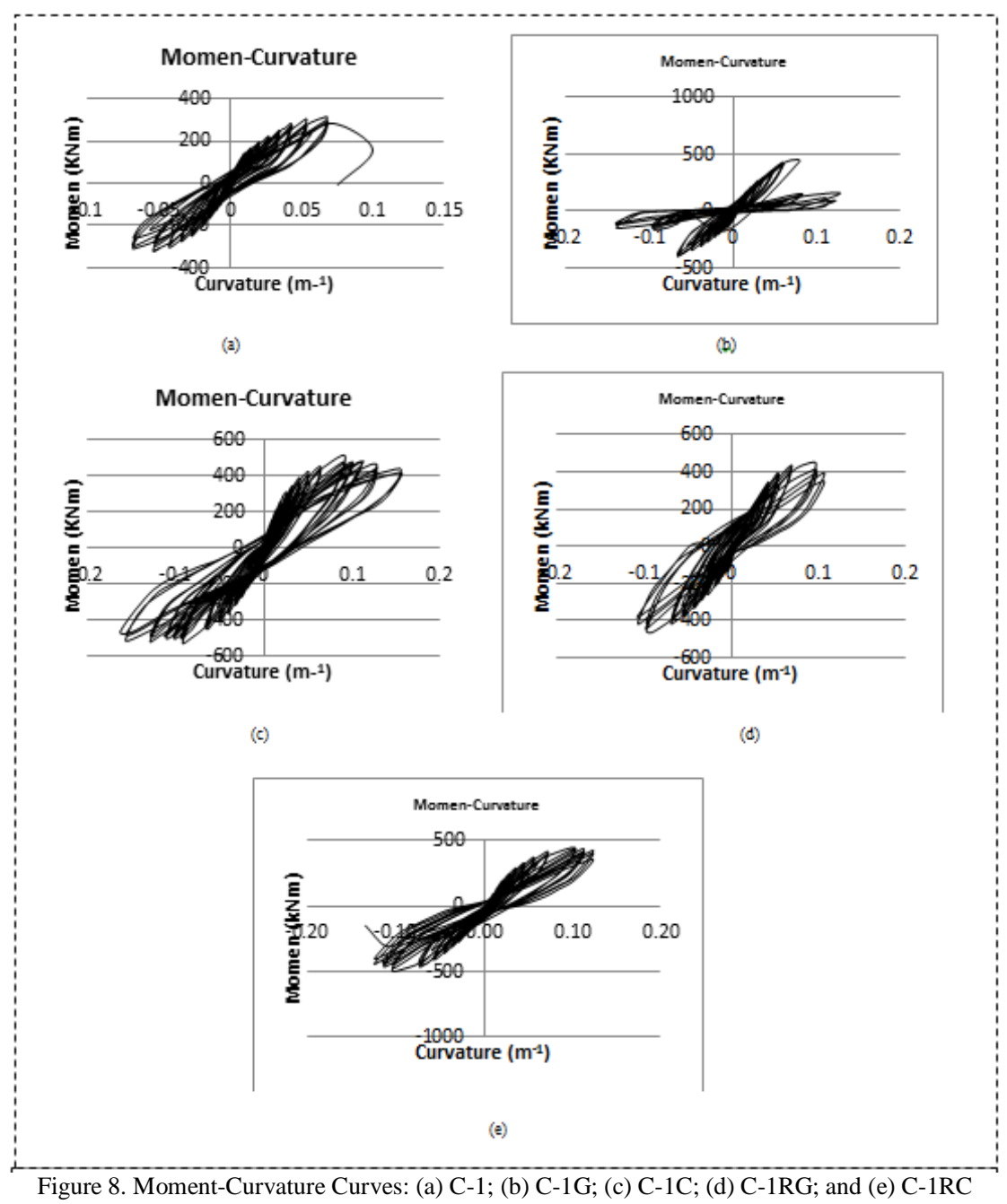

